ARTICOLE

\title{
THE NEW ADMINISTRATIVE PROCEDURE CODE IN HUNGARY
}

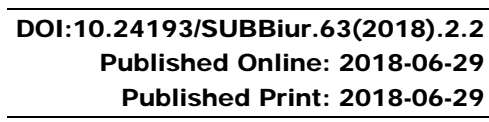

László PRIBULA*

\begin{abstract}
The first Administrative Procedure Code in Hungary came into effect on 1st J anuary 2018. By this, the legislator not only collected and systematised the rules of administrative trials which previously were part of the Civil Procedure Code but also intended to place legal protection against administrative offences on new ground. The apparent goal of the legislator was to widen the administrative judicial gouge, not only against administrative provisions but also to offer the opportunity to turn to the court for strong legal protection in any injury caused by an administrative act. Hopefully, historical traditions, several years of codification, efficient allotment of the knowledge accumulated by the judicial system may all contribute to the further improvement of administrative jurisdiction.
\end{abstract}

Keywords: Hungarian Administrative Procedure Code, control above administration, administrative courts, administrativelegal disputes, reformatory.

\section{Introduction}

The first Administrative Procedure Code in Hungary came into effect on 1st J anuary 2018. The development of administrative jurisdiction then reached an outstanding phase. The most important aim of the creation of the new procedure code was to establish a regulation which is not only built on Hungarian legal traditions but also appropriate for the challenges of the modern times, and which can protect jurisdictional rights over against government administration. The new principles widen the opportunities of 
László PRIBULA, THE NEW ADMINISTRATIVE PROCEDURE CODE IN HUNGARY

thejudiciary remedies by theadministrative courts that support the concentrated conduct of the process, adequate preparation of the process and particular types of administrative processes that adapt to the requirements of the specific case make the deciphering of the practical challenges difficult and vital for the implementation bodies.

\section{Code}

\section{The necessity of creating the new Administrative Procedure}

The creation of a new procedure code is a crucial and peculiar event in a particular country's legal system. In order to ensure adequatelegal protection in Hungary, procedure law is wholly re-established, as on 1st J anuary 2018 the new civil procedure code, and then, on 1st July 2018, the new criminal procedure code is coming into effect. Among these, the Administrative Procedure Code deserves special attention because no such procedure code had ever existed before in Hungary, as it was the first time that the legislator enacted the regulations of administrative trials which are different from civil trials both regarding function and crucial procedural features.

Administrative jurisdiction assures constitutionality and, thus, a means of self-control from the side of the government. It must practice control above administration, thus forbidding unlawful administrativeactions. It has to ensure objectivelegal protection, or theeffectuation of legal regulations, and also subjective legal protection, or the protection of the rights the clients involved in an administrative action, remedying the consequences of a particular offence. Thosetasks accentuate theimportance of theregulations of administrative processes.

The administrative jurisdiction shows a diverse picture in different countries, as there are different regulatory systems for the same protective aim. As Iván STIPTA highlighted it in his detailed study, the British, German and French types of administrative jurisdiction do not adequately reflect the contents of the historically developed protective systems, and none of the European countries has developed a model which could have been efficient in any other countries ${ }^{1}$.

In Hungary, administrativejurisdiction was only partially established, since it involved cases of tax and levies, as the XLIII Act of 1883 established a Financial Administrative Court. The XXVI Act of 1896 established the 
Administrative Court with a national region of activity. The Administrative Court was on the same level as the Curia, as it was independent both from ordinary courts and the establishment of administration. It had two departments: the general department of administration and the department of finance, the latter was formed from the earlier financial administrative courts. Its process had only one level, the judiciary decided irrecoverably, against which no appeal was possible. After the Second World War, the Administrative Court was eliminated as part of the abolishment of constitutionality. First, its effectuation was strictly limited; then, The II Act of 1949 eliminated it alongside with other specialised courts.

In the era of the socialist legal system, administrative jurisdiction could only partially work. From 1957 on the III Act of 1952 (the 1952 Civil Procedure Code) included processes which appealed administrative decisions, but it did not offer the opportunity of reviewing all the decisions, only in some instances which were exhaustively listed in the special laws. Later, from 1972, administrative processes gained an independent chapter.

Even though after the change of the regime by theXXXI Act of 1989, the Law of Constitutional Reform introduced the principle of general judicial review of administrative decisions into Chapter 50 (2) of the Constitution, according to which 'the court controls the constitutionality of administrative decisions', the classification did not change for a period. In its Decision 32/ 1990 (X.22.) the Constitutional Court stated the unconstitutionality of the regulations which enlist the administrative decision that may be appealed by court reviews, the Constitutional Court eliminated the decisions from 31 May 1991, arguing that court reviews must be assured not only in cases of individual decisions but generally. After the decision of the Constitutional Court, the legislator passed the XXVI Act of 1991 about the extension of court reviews of administrative decisions, thus changing the title of Chapter XX of the 1952 Civil Procedure Code to 'Administrative Processes'.

Trials of administrative processes were involved in the general court system until 31 December 2012, administrative and labour courts were founded on 1J anuary 2013, as the successors of the earlier labour courts. The occasional appeals for the decisions of the new courts were discussed by the regional courts, while the appeal procedure was the duty of the highest-level jurisdictional platform, the Curia, thus at the upper levels appeals were organised into the general system of courts, creating a so-called 'pseudo-mixed system'. 
László PRIBULA, THE NEW ADMINISTRATIVE PROCEDURE CODE IN HUNGARY

There is no debate in Hungarian legal literature that the administrative jurisdictional system in Hungary, after the change of the political regime, was not entirely comprehensive, so further improvement was justified. Critiques mostly pointed out that the narrow range of act reviews did not offer legal protection against administrative actions, also highlighting that administrative judges were not acknowledged enough, nor did they not receive the choices of a career that judges, specialised in other areas, did. Many traced this back to the fact that process law regarded administrative processes as special civil processes and found theapplication of traditional tools of civil procedure law sufficient for the efficient jurisdictional control of administration, consequently the opportunities of further improvement of administrative jurisdiction were limited ${ }^{2}$.

In 2013, the overall review of the Civil Procedure Law begun alongside with the development of a new Civil Procedure Code to replace one of thelongest effective law in Hungarian law history. Back then the question was still open whether the procedure regulations of administrative processes would belong to the special processes of the new code, or they would be discussed in an independent law. Eventually - accordingly to an overwhelming majority of Hungarian lawyers and to the regulations of all the European Union countries (except for Slovakia) - in 2015 the legislator decided on creating the first Hungarian Administrative Procedure Code, testifying the necessity of both the improvement of administrative jurisdiction and the intensification of its relativeindependence. ${ }^{3}$ As a result of theprocedure of codification, the Hungarian Parliament passed the I Act of 2017 on administrative procedures which came into force on 1J anuary 2018. The CXXX Act of 2016, on civil procedures, came into force on the very same day.

\section{Conceptual differences between administrative and civil procedures, the different roles of the judge}

Administrative jurisdiction cannot be classified in the range of civil jurisdiction in the broad sense, as there are crucial differences between judging legal disputes of civil law and administrative law, both from the side of the parties procedural positions and consequently the obligation of the judiciary. In civil processes, the parties areco-ordinated, and they can act as autonomous legal subjects in the legal relationship of civil law. Meanwhile, in administrative 
processes, the parties are not co-ordinated. Oneof the parties practises executive power. In this executive power, it makes decisions which regulate the rights and obligations of its clients who are not in a bargain position. In its scope of obligations, it has an advantageous position as opposed to the client in both organisational and personal circumstances. This lack of balance must be avoided by creating guarantees which are - generally - not justified in civil processes.

One of the crucial regulations of administrative procedure law is that the rules of civil procedures must be applied only when it is pronouncedly specified by thelaw; but also, in these cases, they may beapplied in accordance to administrative procedure law. Unlike the previous regulations before 1 January 2018, the presently effective law does not specify the rules of administrative procedures. Administrative procedure rules differ from civil procedures, as theadministrative process is not a special kind of civil process, but they includeall the prescriptions of administrative procedures, and prescribe the application of civil procedural rules only in individual cases taking into account the similarities of both legal institutions. This solution is justified because there are no differences between several legal institutions, depending on whether they are realised in civil or administrative processes. With these referential rules, the unnecessarily lengthy repetitions can be avoided. However, in order to accentuate the independence of administrative processes, the law also states that in these cases the regulations of civil procedures must be applied in accordance with administrative procedures, so the different course and structure of the administrative process must be considered ${ }^{4}$.

The features, which differentiate administrative processes from civil processes, are defined by the obligations of the judiciary. The most important obligation is to assure efficient legal protection and legal remedy against the administration. The judiciary acting in an administrative case must aim to assure legal protection against the administration, which acts presupposes being separated from the administration (a legal subject who is not in any legal relationship with theadministration, including management), and also a right or interest protected by thelaw, which needs legal protection. Administrative judging - which is 'the conscience of the executive power'5 as Ferenc PETRIK put it - has to keep a reasonable distance from theadministration it controls. According to the principle of the balance of power, the court procedure necessary to assure legal protection can be launched exclusively on request. Efficient legal protection requires a dual protective task from the judiciary: 
László PRIBULA, THE NEW ADMINISTRATIVE PROCEDURE CODE IN HUNGARY

subjective legal protection on the one hand, to which a dispositive principle is attached and according to which the legal party can decide whether they want to start a procedure or not. The court judges during the administrative dispute in the framework of the claim, the claims submitted by the parties, and the legal statements whether the proposed claims and statements are to be taken into consideration based not on their form but their content. On the other hand, efficient legal protection allows objective legal protection, which - as a breakthrough in the dispositive principle - in some instances defined by the law allows the court to proceed ex officio, in exceptional cases defined by the law the court can ex officio initiate investigation and proof. Ex officio proceeding does not affect the fundamental principle that the court can act only on request ${ }^{6}$.

\section{Administrative judicial channels}

Since 1J anuary 2018, the procedural rules of administrative processes have been included in a code independently from the civil procedure code. This fact does mean not only the detachment of an earlier special civil process from the civil procedure code but also a qualitative change. The apparent goal of the legislator was to widen the administrative judicial channel, not only against administrative provisions but also to offer the opportunity to turn to the court for strong legal protection in any injury caused by an administrative act. The legislator aspired to form as abstract rules as possible in order to offer the judge enough elbow room and opportunities to handle the newly arising questions, as Krisztina ROZSNYAI, commissioner for the preparation of laws concerning the Administrative Procedure Code, put it in an interview ${ }^{7}$.

According to the new regulation, the judgment of administrative disputes concerns firstly the judicial channel, secondly the decision in a public law dispute which is referred to the administrative court by the law, and thirdly procedures concerning investigations of municipal regulations confronting other regulations, and proceedings on defaults of legislatorial obligations by municipalities ${ }^{8}$.

Threetypes of trials belong under the umbrella of administrativelegal disputes: 1. judicial control of the legality of administrative action; 2 . disputes concerning administrative contracts; 3 . disputes concerning civil service, which were earlier regulated among labour processes. 
The majority of administrative processes are about the judicial control of the legality of administrative action. Their concern is the lawfulness of an act or the lack of action by an administrative body that aims at or results in altering the legal circumstances of the involved legal subject regulated by administrative law (and not by other, e. g. civil law or criminal law). The law enlists the administrative actions against which one cannot turn to a court. There is no dispute concerning government actions (such as accrediting ambassadors), thelawfulness of an ancillary administrativeaction independently, that serves an administrative action (such as approvals, resolutions or actions serving the execution of an administrative action), and also between parties who are in managing or controlling legal status ${ }^{9}$.

The following cases do not belong to the court acting in administrative actions: the legal control of authority actions which cover administrative body as executive authority involved in administrative offences, a property right caseinitiated by a notary, an action of a penal institution substantiating an injury during the period of detention, action by the police in a case of injunction to stay away, or authoritative action by the National Authority for Intellectual Property Rights. In these cases, other courts are to assure legal protection.

The notion of administrative contract is not defined in the Administrative Procedure Code, but it describes such a contract as one that is defined so by a law of a government decision (e. g. authority contracts, association contracts or health financing contracts ${ }^{10}$ ).

Civil service employment relation is a contractual relationship of a person employed by the state or a body acting in the name of the state, and a legal relationship created in order to serve the public, the specific obligations and rights of which are defined in the law (such as the service relation of soldiers, police, government officials), but excluding the servicerelation of judges, judicial employees, employees of public prosecution, and of those employed ${ }^{11}$.

Administrative law belongs to public law; however, the procedure code ensures the administrative judiciary action, as a general rule, exclusively in administrative disputes. In other kinds of public law disputes, namely in disputes of legal bodies and institutions that do not belong to administration, administrative judiciary remedy is available only in cases when thelaw expressly allows it. Aboveall, the judicial action is availablein actions which are referred to the Curia, regulated in detail among administrative trials, and which are aimed to investigate a municipal provision conflicting another regulation or the municipal law's legislatorial default (control of legislation). 
László PRIBULA, THE NEW ADMINISTRATIVE PROCEDURE CODE IN HUNGARY

\section{Court acting in administrative trials}

The role of legal protection by administrative jurisdiction is in no direct correlation with the structure of the court system or the foundation of independent administrative courts. As András PATYI put it, 'the system serves as a tool. Its aim and the content is the measure and the how of legal protection, and thus the scope of judicial power'12. To specify the courts acting in administrative trials we need to mention that in 2016 the legislator aimed to create a system of administrative courts fully independent from the general court system, except for the uppermost level (regional administrative courts - Administrative Appeal Court - the Curia), which then could not be realised without the amendments of the constitutional acts. After the effectuation of the Administrative Procedure Code, the legislator initiated concentrated administrative jurisdiction through the competency rules, as in the majority of administrative trials eight regional administrative and labour courts act on the first level; while in certain cases typically involving citizens searchingfor their rights - such as social insurance, social care, child protection, cases involving care or support provided by a government employment body, or in trials on public service- all the twenty (municipally organised) administrative and labour courts act. In certain important cases theadministrative trial - such as trials involving the railway management body, the air traffic authority, the administrative actions of the Hungarian Central Bank, trials involving the practice of the freedom of assembly, trials involving the publication of qualified data - belongs to the Budapest-Capital Regional Court, which has national jurisdiction, and which belongs to the general court system. In exceptional cases the Curia gets the first-level jurisdiction in administrative trials: Curia conducts control procedures of municipal legislation and actions aiming to ascertain a constitutional dispute.

If the case starts on the first-level administrative and labour court, appeals against the judgments are judged by the Budapest-Capital Regional Court; the exceptionally permitted review process belongs to the Curia. If the lower-level court is the Budapest-Capital Regional Court, the appeals are judged by the Curia, in these cases, there is no appeal. If - exceptionally the case starts at the Curia, then against the decisions of the Curia there is neither appeal nor review ${ }^{13}$. On 20 J une 2018, the Hungarian Parliament adopted an amendment to the Fundamental Law, which distinguishes between ordinary courts and administrative courts in the future: ordinary courts - 
whose main body is the Curia - decide in criminal cases, in private law and in other cases defined by the law, while administrative courts - whose main body is the Administrative Appeal Court - decide in administrative disputes and in other cases determined by the law ${ }^{14}$. The creation of a wholly separated administrative court system will be a matter for the legislature in the near future.

\section{The Crucial Regulations of Administrative Trials}

The general rule is associate judging: the court acts as a council of three professional judges. Exceptionally, in cases of minor value or needing faster action, however, one single judge acts in an administrative trial. As a result of the easy or difficult assessment, there is the opportunity of referring the case from the council to one single judge or vice versa, from the single judge to a council of judges ${ }^{15}$.

In an administrative trial, locus standi is limited by the law: action can be brought only by the claimants specified by the law only against the respondents specified by the law. Primarily direct concernment is the basis of bringing administrative action. A claimant can be a person whose right or lawful interest is concerned by an administrative act. Since the administrative jurisdictions mainly assure subjective legal protection, the person is entitled to bring an action who claims that their right or legitimate interest is injured directly by the disputed action of administration. In exceptional cases however - in order to protect common interest - the prosecutor, the body practising legal control, the administrative body involved in the disputed administrativeact can bring action, and also - in thearea of operation of interest protection - a civil body, an interest protection body, and public bodies. In an administrative trial, the claim must be instituted by the claimant against the administrative body which effectuated the disputed administrative action.

Based on the law, however, a non-administrative body can also act as claimant, since as a result of the administrative contract, and in a public service dispute, the administrative body is entitled to enforce its claim as a claimant, based on the legal relation. In a dispute based on an administrative contract, the other contracting party can be the claimant, while in an administrative dispute the natural person as an employee ${ }^{16}$.

There are important rules regarding the particular legal party of the administrative trial, namely the concerned party. Typically, in an administrative 
László PRIBULA, THE NEW ADMINISTRATIVE PROCEDURE CODE IN HUNGARY

trial, the claimant is a person searching for protection because of a legal injury caused by an administrative body, while the respondent is the administrative body itself. Administrative relation, however, is not collateral, but multilateral, the subjects of which often carry different interests. The client having taken part in the previous administrative act, but not bringing administrative action, is entitled to the samerights and obligations as the claimant, so it is reasonable to offer them the opportunity to take part in the trial. The person not taking part in a trial, but whose right or interest may directly be affected by thejudgment to be made in the process, may join the process between other persons as a concerned party. The precondition of joining a process as a concerned party is that they need to be directly concerned in the case. The party concerned is entitled to the same process rights and obligations. However, the certain rules of the law may diverge. (Thus, receding from the claim is only the right of the claimant, but not of the concerned) ${ }^{17}$.

Therules of bringing an action adjust to the specialities of administrative processes. the CL Act of 2016 on the general Administrative Procedure Code (Hungarian: 'Ákr.') only specifies theguarantee framework of theadministrative process. The client may bring administrative action against the final decision, except for court decisions that cannot be appealed. In case of an appealable decision, administrative action may be brought if one of the entitled persons appealed and the appeal has been judged. In case of taking administrative action for the correction of the injury takes place primarily inside the administrative structure system: if the court assesses that the decision offends a law, the decision is modified or annulled. If the appeal court agrees with the content of the statement of claim, and there is no party in the case with opposing interest, the authority may also annul the decision which does not offend a law or may modify it according to the statement of claim. If the administrative body did not annul or modify the questioned decision in its competency, the administrative court is to judge the administrative dispute ${ }^{18}$.

The statement of claim must be presented to the administrative body which realised the disputed act within thirty days from the announcement of the disputed administrative action, pleading a violation of rights. In case the administrative act is not to be announced, the statement of claim must be presented within thirty days from the day of obtaining knowledge about the act, but no later than within oneyear from the realisation of the act, if the law does not regulate otherwise. In the statement of claim the claimant may demand 
the repeal, the annulation or the modification of the administrative action; the ascertaining of the default in administrative act; the forbidding of the administrative action; the obligation of theobligatory act based on administrative legal relation; the obligation of compensation for the injury in connection to the administrative contract relation or administrative legal relation; and the ascertaining of the fact of injury caused with an administrative action or any further crucial fact from the point of view of the administrative legal relation - but the latter only in case when the ascertaining is necessary in order to prevent the rights of the claimant against the respondent, and no further statement of claim is possible. Thus, the statement of claim must contain the exact decision or decisions that the claimant demands from the court ${ }^{19}$.

After the claimant presented thestatement of claim to theadministrative body, theadministrativebodymust send on thestatement of claim to thecompetent court within the period specified in the law - as the main rule, within fifteen days - together with the documents of the case. The respondent presents the documents of the defence simultaneously with the forwarding of the statement of claim and the documents of the case. The document of the defence is different from the defence request applied in a civil process, it is the statement of the respondent which refuses the statement of claim or contains substantive defence ${ }^{20}$.

Immediate legal protection is a new institution. The purpose of the administrative trial is to assure legal protection for the claimant's right or against the administrative action injuring their right through the judicial channel. Even though the presentation of the statement of claim does not have a retarding effect, some of the administrative actions have contents that the original circumstance cannot or would disproportionately be difficult to be restored after the effectuation of the judicial decision. Consequently the judicial legal protection would be pointless as a result of the procedure. In order to promote effective legal protection, the law offers judicial legal protection before the decision, regulating them in a chapter as an immediate tool for legal protection.

The presentation of the statement of claim does not have a retarding effect on the implementation. However, the claimant can demand immediate legal protection in the statement of claim. As part of the immediate legal protection the retarding effect may be required, the release of the retarding effect, the disposal of a temporary act, or of previous proof. When weighing the proportionate necessity of immediate legal protection, the judiciary must 
László PRIBULA, THE NEW ADMINISTRATIVE PROCEDURE CODE IN HUNGARY

consider the interests for and against the effectuation of the administrative action and the results of theinjury, especially whether the default of immediate legal protection cause more serious injury than the assurance of immediate legal protection ${ }^{21}$.

The regulation of the preparation of the process is special too. Unlike the civil trial, the administrative trial is not divided into two stages, the initiation of the process and the substantive hearing. The peculiarity of the unified process structure is, however, that in case the statement of claim is appropriate for substantive judgment, the judiciary has a council meeting within fifteen days after the reception of the statement of claim - even if one single judge judges the case- , then, within thirty days after the reception of the statement of claim, the judiciary arranges either the deadline date of the hearing, or the judging of the case without a hearing. During the preparation phase of the process, any action is feasible which is necessary for the hearing (judging without a hearing), or the finishing of the process before the deadline. At the preparative council meeting the judiciary may ordain proof to prepare the substantive judgement, may require documents from another court or authority, may ordain the hearing of the parties, may attempt to generate agreement between the parties, and decide whether they refer the case to a council or one single judge 22 .

The general rule in the administrative trial is judgement without a hearing. If none of the parties demanded a hearing, and the court does not consider it necessary, the judiciary decides substantially without a hearing. Either party may request a hearing. On demand, it is obligatory to hold a hearing. The judgment of the case is impossible without a hearing if proof is necessary - document verification is not included here ${ }^{23}$.

The significant innovation of the law is the introduction of the muster process. The purpose of the regulation is to handle disputes where the judiciary has to judge collaterally several cases based on similar facts, in similar legal circumstances, and thus take nearly similar actions to do so. The procedure law allows the judiciary to qualify the procedure a muster process so that such procedures may be judged more quickly. In these cases, the judiciary may use the evidence and the law interpretation gained in the muster process for the judgement of the similar trials. If at least ten procedures are initiated at the court, procedures which have similar legal and factual grounds, the judiciary may decide to judge one of the trials in a muster process and suspends the rest of the procedures until the final decision. The parties to the 
suspended procedures do not have to approve the suspension, neither do they take part in the muster process as concerned parties. After finishing the muster process, the judiciary may judge the suspended procedures without a hearing, according to the result of the muster process. In the muster process, the judiciary may ordain that the costs of proof during the proceeding are advanced or sponsored by the state ${ }^{24}$.

During the substantial judgement of the claim the greatest innovation is that compared to the earlier law instead of the primarily cassation power of the judiciary, the reformatory power is the foregrounded. The judiciary refuses the claim if the claim is unfounded, the direct injury of the right or the lawful interest of the claimant cannot be ascertained, or there has been such a procedural offence which did not affect the substantial judging of the case. However, if the claim is well-founded, that is, the right or the lawful interest of the claimant was injured, or there has been an offence affecting the substantial judgement, then the reformatory power of the court is in the foreground. Accordingly, the judiciary amends the offensive administrative action if the nature of the case makes it possible, the statement of facts is properly clarified, and the dispute can be irrecoverably judged based on the available evidence. In every single case needs it to be investigated whether amendment is possible. However, even though the claim is well-founded, but no amendment can be done, then the judiciary annuls or countermands the administrative action, and obliges the administrative body to a new procedure. Annulment is effective ex-post facto to the realisation date of the administrative action. In exceptional cases - if the annulation offends important public interest, legal certainty, or the interests of persons concerned by the action - the judiciary is allowed to countermand the decision from a specified date, thus pronouncing it effective up to that date. The difference between annulation and countermanding lies in the date from which the administrative action is effective ${ }^{25}$.

Legal remedies are regulated characteristically. Appeal against the decision of the court does not lieas a general rule. Exceptionally appeal against the decision of the court lies - within fifteen days after its announcement if the law allows (e. g. against a decision in a default trial, condemnation trial). If the trial belongs to the Budapest-Capital Regional Court in the firstinstance, appeal always lies against the decision. The second-instance court decides without a hearing, although, on the party's request, they hold a hearing. 
László PRIBULA, THE NEW ADMINISTRATIVE PROCEDURE CODE IN HUNGARY

As a general rule, there is no appeal against the judgement of a court, appeal is possible only if the law expressly allows it ${ }^{26}$.

In some instances, review is available in administrative trials as exceptional legal remedy. Unlike civil trials, no review pleading is possible as a subjective right, if the law regulates that review is for some reason impossible, the Curia previously decides in each case whether it can accept the claim at the first-instance court within thirty days after the announcement of the final decision. The Curia accepts the review pleaif the review of the offenceis justified based on one of the following reasons:

- to assure the unity or the improvement of the legal practice,

- the special significance or social importance of the legal issue,

- the necessity of the previous regulatory procedure by the Court of the European Union,

- or there is a decision which differs from the earlier practice of the Curia ${ }^{27}$.

The earlier procedure law modelled only one general administrative trial, while in the new law there are the so-called specific administrative processes which bear different features. Among these, simplified processes are regulated uniquely. There are specific simple administrative actions the disputes of which require faster judging than usual (for instance trials concerning official passes, official certificates, or the conduct of official registry). Simplified processes promote faster judgement since the court can omit the preparatory council meeting. The court may write a memorandum instead of an official record; appeal against the warrants is possible within eight days following the announcement; and there is no appeal against the final decision ${ }^{28}$.

The default process is a new institution, which offers legal protection against the lack of action or the passivity of the administrative body. A trial following the procedural rules of the simplified process assures legal protection in a case when theadministrative body does not obey some obligation founded inlaw. If thereis asuperior administrative body abovethe defaulting administrative body with a managing or supervising power, then first the legal remedy must be attempted through the superior body. After this attempt, is it possible to turn to the administrative court? If the claim is well-founded, the court ascertains the default, and the defaulting body is obliged to accomplish the act within the period specified in the law 29 .

Another crucial improvement involves the implementation of the judicial decisions. If the administration body defaults in paying the imposed 
fine, the regulations of the law about the implementation of the judicial decisions must be applied. If the administrational body fails to initiate the necessary new action imposed on it by the countermanding decision, or in a default trial the obligation of action, the action can be enforced by a procedure which promotes the obligation for new action and enforce a default judgment. The judiciary warns the administrative body within fifteen days to accomplish its obligation or give a written explanation for the default of accomplishment, also attaching the demonstrative documents.

If the administrative body obeys the warning, the judiciary annuls the procedureand obliges theadministrative body to recompense the costs of the claimer. If the administrative body does not accomplish its obligations, the judiciary has several sanctions to reinforce accomplishment: it imposes an accomplishment fine on the administrative body, imposes an accomplishment fine on the leader of the administrative body, it assigns another body with the procedure with the same competence as the administrative body, it authorises the control body of the administrative body to accomplish the default judgment, or it takes temporary measures which are capable of remedying the injury caused by the default and which are effective until the accomplishment ${ }^{30}$.

\section{Conclusion}

The creation of the new Administrative Procedure Code was an essential phase of Hungarian legal history. By this, the legislator not only collected and systematised the rules of administrative trials which previously were part of the civil procedure code but also intended to place legal protection against administrative offences on new grounds. A new procedure code, however, can become an organic part of recent law through its practical application. The jurisprudence of the near future has to fill the new procedural institutions with content, to solve the newly arising problems. Hopefully, historical traditions, several years of codification, efficient allotment of the knowledge accumulated by the judicial system may all contribute to the further improvement of administrative jurisdiction.

\footnotetext{
* Habil. Dr. associate professor, University of Debrecen, Faculty of Law - Head of Civil Procedure Law Department. Email: pribula74@freemail.hu.

1 STIPTA, István: A közigazgatási bíráskodás történeti modelljei. (Historical models of administrative jurisdiction') J ogtörténeti Szemle, 2015/3, 45.
} 
2 The most detailed analysis of the necessity to improve administrative jurisdiction is offered in ROZSNYAI, Krisztina: Közigazgatási bíráskodás Prokrusztész-ágyban ('Administrative jurisdiction in Procrustes' Bed.') ELTE Eötvös Kiadó 2010., PATYI, András: Közigazgatási bíráskodásunk modelljei. Tanulmány a magyar közigazgatási bíráskodásról. ('Models of administrative jurisdiction - Study on Hungarian administrative jurisdiction.') Logod Bt. 2002., TRÓCSÁNYI, László: Milyen közigazgatási bíráskodást? ('What kind of administrative jurisdiction?') Közgazdasági és J ogi Könyvkiadó 1992.

${ }^{3}$ Hungarian Government Resolution 1011/2015 (I.22.).

${ }^{4}$ Administrative Procedure Code (Hungarian: „Kp.”) §.6.

${ }^{5}$ PETRIK, Ferenc: Közigazgatási bíráskodás, a végrehajtó hatalom lelkiismerete. ('Administrative jurisdiction, the conscience of executive power') J ogtudományi Közlöny, 2001/ 11, 457.

${ }^{6} \mathrm{Kp} . \S .2$.

7 'A jogállamiság nem egy olcsó dolog' - Interjú Rozsnyai Krisztinával ('Constitutionalism is not cheap' - interview with Krisztina ROZSNYAI) http://arsboni.hu/a-jogallamisag-nemegy-olcso-dolog-interju-rozsnyai-krisztinaval-i-resz/ (2017.10.16.).

${ }^{8}$ Kp. §.5.

${ }^{9}$ Kp. §.4. (1)., (4).

10 Kp. $\S .4$ (7). 2.

11 Kp. §.4. (7). 3.

12 PATY, András: Közigazgatási bíráskodás de constitutione ferenda. ('Administrative jurisdiction de constitutione ferenda'), in: Varga Zs., András - Fröhlich, J ohanna (editors), Közérdekvédelem. A közigazgatási bíráskodás múltja és jövője. ('Public interest protection. Past and future of administrative jurisdiction'.), PPKE J ÁK-KIM 2011, 52-55.

${ }^{13}$ Kp. §.7., 12.-13.

${ }^{14}$ The Fundamental Law of Hungary $\S .25$ (2), (3).

${ }^{15} \mathrm{Kp} . \S .8$.

${ }^{16}$ Kp. §.17.-18.

${ }^{17}$ Kp. §.20.

18 Ákr.114.-115.

${ }^{19}$ Kp. §.37.-39.

20 Kp. §.40., 42.

21 Kp. §.50.-55.

22 Kp. §.56.-58.

23 Kp. §.77.

24 Kp. §.33.

${ }^{25}$ Kp. §.88.-90., 92.

${ }^{26}$ Kp. §.99., 107., 112.

${ }^{27} \mathrm{Kp} . \S .118$.

28 Kp. §.124.- 126.

29 Kp. §127.-129.

30 Kp. §151.-152. 